\title{
The reaction of Amaranthus hybridus to infection by Amaranthus mosaic virus
}

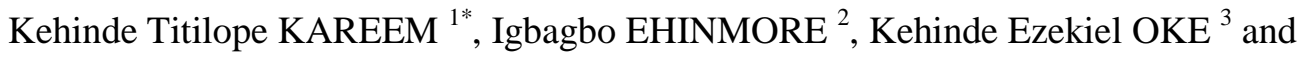 \\ Olawale AROGUNDADE ${ }^{4}$ \\ ${ }^{I}$ Citrus Improvement Programme, National Horticultural Research Institute, PMB 5432, Jericho, Idi-ishin, \\ Ibadan, Nigeria. \\ ${ }^{2}$ Department of Botany and Microbiology, University of Lagos, Akoka, Yaba, Nigeria. \\ ${ }^{3}$ Vegetable Improvement Programme, National Horticultural Research Institute, PMB 5432, Jericho, Idi-ishin, \\ Ibadan, Nigeria. \\ ${ }^{4}$ Fruit and Spices Improvement Programme, National Horticultural Research Institute, PMB 5432, Jericho, \\ Idi-ishin, Ibadan, Nigeria. \\ *Corresponding author; E-mail: rabkareem2@yahoo.com;08024158641
}

\begin{abstract}
This study investigated the effect of inoculating three Amaranthus hybridus cultivars: NHAM/114, NH84/457-IL and LOCAL GREEN cultivar with Amaranthus mosaic virus (AMV) consecutively for four weeks. Results indicated significant differences between the control and virus inoculated plants. Severity of infection by the virus was more pronounced in plants inoculated at early ages while the effect was very mild on plants inoculated at later stage of growth. Reduced weight values were recorded in plants with early infection compared to plants inoculated at later stages of growth. Mean values of $0.190,0.250$ and $0.218 \mathrm{~g}$ were obtained for fresh weights of leaves of NHAM/114, NH84/457-IL and LOCAL GREEN respectively at 2 weeks after planting (WAP) while plants that were inoculated at 5 WAP had average values of $0.516,0.392$ and $0.397 \mathrm{~g}$ fresh weights of leaves for the three cultivars respectively. The percentage decrease in fresh weight of stem of the LOCAL GREEN cultivar was above average (56\%) and higher than those of NHAM/114 and NH84/457IL. NHAM/114 produced the least dry weights in stem while the highest dry weights were recorded for NH84/457-IL at all the stages of inoculations. These results indicated that infection at an early age resulted in greater reduction of the parameters assessed.
\end{abstract}

(C) 2011 International Formulae Group. All rights reserved.

Keywords: Cultivars, Inoculation, Severity, Weeks after planting (WAP), Plant weight.

\section{INTRODUCTION}

Amaranthus hybridus L. (Smooth pigweed) is an annual plant, native to eastern North America and parts of Mexico, Central America and northern South America (Weaver and McWilliams, 1980). The genus Amaranthus includes species cultivated as leafy vegetables and/or for their grains (i.e. pseudocereal) in several developed and developing countries (Harlan, 1992). Amaranthus hybridus is a fast growing plant producing up to six generations per year. It is eaten as a leafy-vegetable crop and is high in proteins, carbohydrates and lipids (Rawate, 1983). In Nigeria, A. hybridus leaves combined with condiments are used to prepare soup (Oke, 1983; Mepha et al., 2007). In Congo, their leaves are eaten as spinach or 
green vegetables (Dhellot et al., 2006). These leaves boiled and mixed with a groundnut sauce are eaten as salad in Mozambique (Oliveria and DeCarvalho, 1975) or pureed into a sauce and served over (farinaceous) vegetables in West Africa (Martin and Telek, 1979).

Amaranthus hybridus has been shown to contain large amount of squalene, a compound that has both health and industrial benefits (Rao and Newmark, 1998; Smith, 2000; He and Corke, 2003). Several studies have shown that amaranth seed or oil may be of benefit for those with hypertension and cardiovascular disease; regular consumption reduces blood pressure and cholesterol levels, while improving antioxidant status and some immune parameters (Czerwiński et al., 2004; Gonor et al., 2006; Martirosyan et al., 2007). Amaranth appears to lower cholesterol via its content of plant stanols and squalene. The consumption of Amaranthus species is known to prevent ahypovitaminosis and anaemia (Reiz and Leitzmann, 1985). In addition, they have ornamental uses and contribute to the income of small scale farmers, especially during the dry season, in Nigeria (Taiwo and Owolabi, 2004a).

Virus diseases have been recognized to constitute one of the major factors limiting vegetable crop production worldwide (Grogan, 1980). In Africa, they sometimes result in significant yield losses (Ladipo, 1988). A number of viruses have been reported to infect Amaranthus species. Some of these include: Cucumber mosaic virus (Schmelzer and Molnar, 1975), Alfalfa mosaic virus (Rogers, 1969), Amaranthus leaf mottle virus (Lovisolo and Lisa, 1979), Pigweed mosaic virus (Singh et al., 1972) and Amaranthus mosaic virus (Phatak, 1975). A sap transmitted virus was isolated from the leaves of naturally infected $A$. hybridus plants. The virus induced mosaic or mottling, green vein banding and malformation of leaves of inoculated Amaranthus plants. It also infected Nicotiana benthamiana and Chenopodium amaranticolor but failed to infect several other plant species. The results of the investigation indicated that the symptom observed in A. hybridus was incited by a mechanically transmissible virus possibly of the Potyvirus group named Amaranthus mosaic virus (AMV) (Taiwo et al., 1988). Amaranthus mosaic virus was efficiently transmitted by starved Aphis craccivora and Myzus persica, transmission rates of $40 \%$ and $100 \%$ were observed with un-starved and starved aphids respectively. Starved single aphids also transmitted efficiently, suggesting a non- persistent method of transmission (Taiwo and Owolabi, 2004b). This research was conducted to examine the severity of AMV on the three Amaranthus cultivars and to investigate the effect of AMV on the weights of fresh and dry plants of A. hybridus inoculated at various ages in the greenhouse.

\section{MATERIALS AND METHODS}

Sources of viral isolate and Amaranthus species

The AMV isolate used for this research was the original Lagos isolate (Taiwo and Owolabi, 2004b) that had gone through single lesion culturing and was stored over calcium chloride at $4{ }^{\circ} \mathrm{C}$. At the time of use, it was inoculated into healthy Amaranthus plant in the greenhouse.

Seeds of two A. hybridus lines, NHAM/114 and NH84/457-IL were obtained from the National Horticultural Research Institute (NIHORT), Ibadan. Seeds of the LOCAL GREEN cultivar were obtained from vegetable growers at Abule-Ado in Lagos State.

\section{Experimental design}

Plots were arranged in a completely randomized block design. Factors used as the main effects were Amaranthus cultivar/lines (3 levels), inoculation treatment (2 levels) and age of plants at inoculation (4 levels). Four replications were used and a total of 96 plants were used in the inoculation experiment.

\section{Planting and greenhouse conditions}

In the greenhouse, seeds of $A$. hybridus were planted in perforated plastic pots filled 
with loam soil. The soil was sterilized by heating at $100{ }^{\circ} \mathrm{C}$ for $3 \mathrm{hrs}$ to eliminate soilinhabiting microorganisms and enriched with farmyard manure. A total of twenty four pots per variety of the Amaranthus cultivar at the rate of 3 seeds per plastic pot were used on 6th March, 2008. The seedlings were constantly watered and weeds removed. Before inoculation, seedlings were thinned out to one (1) plant per pot for better growth. All the plants were kept in a greenhouse with temperature at $25-28{ }^{\circ} \mathrm{C}$ until inoculation began.

\section{Inoculation experiment}

Wounding and inoculation: At exactly two weeks after planting (WAP), the first set of inoculations was carried out. Sap was prepared by grinding $1.0 \mathrm{~g}$ of virus infected leaves in $10 \mathrm{ml}$ of $0.05 \mathrm{M} \mathrm{K}_{2} \mathrm{HPO}_{4} \mathrm{pH}$ (7.5) buffer. Plants were dusted with carborundum before inoculation. This treatment as well as buffer (control) was rubbed onto fully expanded newest leaves of each plant in each pot. A total of 24 pots were inoculated, out of which 12 pots were inoculated with the virus and the remaining 12 inoculated with buffer. Similar procedure was repeated at 3,4 , and 5 WAP. After inoculation, the inoculated leaves were rinsed with water immediately to reduce the effects of wounding on leaves. The inoculated plants were kept in the greenhouse situated at the botanical garden of the University of Lagos. Pots were spaced (25.40 cm-35.56 cm apart) in order to prevent mechanical transmission within plants. The door of the greenhouse was always kept shut to keep away insects that could transmit viruses to the plants.

\section{Determination of severity of infection of AMV on A. hybridus}

The rating of severity of AMV on $A$. hybridus was done on a scale of $0-5$ : where $0=$ no symptoms; $1=$ slight mosaic or mild mottle on leaves; $2=$ mosaic or mottle on leaves; $3=$ blistering or chlorosis on leaves; $4=$ any of leaf deformation, leaf distortion, leaf curling or leaf reduction while $5=$ death of plants, stunting or combination of two or more symptoms stated above (Fauquet and Fargette, 1990).

\section{Effects of viral infection on plant growth}

In order to determine the effect of viral infection on fresh and dry weights of leaf and stem per plant, plant from each treatment inoculated with AMV was harvested at 3 weeks after inoculation and the leaves were detached and weighed with a sensitive weighing balance to obtain fresh weight. Fresh stem tissue from each plant was also weighed. After obtaining the mean fresh weights, the plants were dried to constant weights in the oven after which the mean dry weights for both leaves and stems were determined. Similar data were obtained for buffer inoculated control plants. The percentage reductions in both the fresh and dry weights of leaves and stems were calculated by expressing the difference between the weights of buffer and virus inoculated plants as a percentage of the value for the weight of buffer inoculated plant.

$\%$ reduction $=\left[\left(\mathrm{W}_{\mathrm{B}}-\mathrm{W}_{\mathrm{V}}\right) / \mathrm{W}_{\mathrm{B}}\right] \times 100$ Where $\mathrm{W}_{\mathrm{B}}$ = weight of buffer inoculated leaf or stem; $\mathrm{W}_{\mathrm{V}}=$ weight of AMV inoculated leaf or stem.

\section{Statistical analysis}

All the data were subjected to statistical analysis. The statistical package for social scientist (SPSS) version 16.0 was used for the analysis of the data obtained. Duncan's multiple range test (DMRT) was used to determine the level of significance between the virus/buffer treatments and age of plant at the time of inoculation at $5 \%$ probability level.

\section{RESULTS}

\section{Effects of AMV inoculation on the three Amaranthus cultivars}

All the three Amaranthus cultivars used in this investigation were susceptible to AMV when they were mechanically inoculated with the virus. The plant age at inoculation had profound effect on the symptom severity (Table 1). AMV did not 
produce any symptoms on the NIHORT lines inoculated at the $5^{\text {th }}$ week after inoculation while a very mild effect was recorded in the LOCAL GREEN cultivar one week after. Once the infected leaves have dropped, symptoms were not produced in the LOCAL GREEN cultivars during the subsequent weeks of observation at the $5^{\text {th }}$ week (Table 1). However, at 2 and $3 \mathrm{WAP}$, the severity was high in the three cultivars and even increased as the weeks of observation progressed. The same pattern of symptom development was seen at 4 WAP though disease severity was not as high in these older plants (Table 1).

The result of the viral treatment on fresh and dry weights of leaves showed that there were significant differences between virus and buffer inoculated (control) plants. Generally, the values of the controls were higher than those of the virus infected plants. Moreso, early infected plants (2-3 WAP) had lower weights than late inoculated plants (4-5 WAP) (Tables 2 and 3). For the dry weights of stems, there were statistical differences between the controls and the virus infected plants at all inoculation ages except at 4 and 5 WAP, in which virus inoculated plants of all the three cultivars had comparable values with the controls (Table 3). Similarly, the effects of the virus on the dry weight of the stem resulted in $24-53 \%, 18-35 \%, 8-9 \%$ and $5-$ $6 \%$ reductions for plants inoculated at 2, 3, 4 and 5 weeks of ages respectively (Table 5).

Inoculations at 4 and 5 WAP resulted in significantly smaller percentage reductions in both leaf weights than early inoculations. At 2 WAP, reductions of $47 \%, 22 \%$ and $39 \%$ were obtained in fresh weights of leaves while $26 \%, 37 \%$ and $49 \%$ were recorded in dry leaf weights in the Amaranthus cultivars NHAM/114, NH84/457-IL and LOCAL GREEN respectively (Table 4).

Infection by AMV caused reduction in the fresh weights of stems of the three Amaranthus cultivars at all the inoculation stages. Reductions were $11 \%, 4 \%$ and $6 \%$ for plants inoculated at 5 WAP while those inoculated at $2 \mathrm{WAP}$ were $49 \%, 27 \%$ and $56 \%$ for NHAM/114, NH84/457-IL and LOCAL GREEN cultivars respectively (Table $5)$.

Table 1: Severity of infection of Amaramthus mosaic virus on three Amaramthus hybridus cultivars.

\begin{tabular}{lllll}
\hline PAI (Weeks) & PAO (Weeks) & NHAM/114 & NH84/457-IL & LOCAL GREEN \\
\hline 2 & 3 & $2.0 \mathrm{~b}$ & $2.3 \mathrm{~b}$ & $2.0 \mathrm{~b}$ \\
& 4 & $2.6 \mathrm{bc}$ & $2.6 \mathrm{bc}$ & $3.0 \mathrm{c}$ \\
& 5 & $4.3 \mathrm{~d}$ & $4.6 \mathrm{e}$ & $5.0 \mathrm{e}$ \\
3 & 4 & $2.4 \mathrm{~b}$ & $2.6 \mathrm{bc}$ & $2.0 \mathrm{~b}$ \\
& 5 & $2.6 \mathrm{bc}$ & $2.8 \mathrm{bc}$ & $3.6 \mathrm{~cd}$ \\
& $6.8 \mathrm{~cd}$ & $4.3 \mathrm{~d}$ & $4.6 \mathrm{e}$ \\
4 & 5 & $1.0 \mathrm{ab}$ & $1.0 \mathrm{ab}$ & $2.0 \mathrm{~b}$ \\
& 6 & $2.2 \mathrm{~b}$ & $2.5 \mathrm{bc}$ & $3.0 \mathrm{c}$ \\
5 & 7 & $3.0 \mathrm{c}$ & $3.0 \mathrm{c}$ & $3.4 \mathrm{c}$ \\
& 6 & $0.0 \mathrm{a}$ & $0.0 \mathrm{a}$ & $1.0 \mathrm{ab}$ \\
& 7 & $0.0 \mathrm{a}$ & $0.0 \mathrm{a}$ & $0.0 \mathrm{a}$ \\
Control & 8 & $0.0 \mathrm{a}$ & $0.0 \mathrm{a}$ & $0.0 \mathrm{a}$ \\
\hline
\end{tabular}

$\mathrm{PAI}=$ Plant age at the time of inoculation in weeks, $\mathrm{PAO}=$ Plant age at the time of observation in weeks, Values are means of four replicates. In each column, means followed the same letter are not significantly different according to Duncan's multiple range test at $\mathrm{P}=0.05$. Control plants were inoculated with buffer only at the same intervals as plants were inoculated with the virus but none developed symptoms.

$0=$ no symptoms; $1=$ slight mosaic or mild mottle on leaves; $2=$ mosaic or mottle on leaves; $3=$ blistering or chlorosis on leaves; $4=$ any of leaf deformation, leaf distortion, leaf curling or leaf reduction while $5=$ death of plants, stunting or combination of two or more symptoms stated above. 
Table 2: Effect of buffer and Amaranthus mosaic virus inoculations on the fresh weights (g) of leaf per plant and stem of the three Amaranthus hybridus cultivars.

\begin{tabular}{|c|c|c|c|c|c|c|c|}
\hline \multirow{2}{*}{\multicolumn{2}{|c|}{$\begin{array}{l}\text { PAI } \\
\text { (Weeks) }\end{array}$}} & \multicolumn{2}{|c|}{ NHAM/114 } & \multicolumn{2}{|c|}{ NH84/457-IL } & \multicolumn{2}{|c|}{ LOCAL GREEN } \\
\hline & & leaf & stem & leaf & stem & leaf & stem \\
\hline \multirow{2}{*}{2} & $\mathrm{~V}$ & $0.190 \mathrm{a}$ & $2.680 \mathrm{a}$ & $0.250 \mathrm{a}$ & $3.912 \mathrm{a}$ & $0.218 \mathrm{a}$ & $2.099 \mathrm{a}$ \\
\hline & B & $0.355 b$ & $5.301 \mathrm{~b}$ & $0.319 \mathrm{ab}$ & $5.389 b$ & $0.359 b c$ & $4.712 \mathrm{~b}$ \\
\hline \multirow[t]{2}{*}{3} & $\mathrm{~V}$ & $0.339 b$ & $4.559 \mathrm{ab}$ & $0.285 \mathrm{ab}$ & $5.352 \mathrm{~b}$ & $0.267 \mathrm{ab}$ & $5.348 b$ \\
\hline & B & $0.426 \mathrm{c}$ & $6.868 \mathrm{~b}$ & $0.352 b c$ & $6.646 \mathrm{c}$ & $0.374 b c$ & $8.794 \mathrm{~cd}$ \\
\hline \multirow[t]{2}{*}{4} & V & $0.459 \mathrm{~cd}$ & $7.457 \mathrm{c}$ & $0.374 b c$ & $7.893 \mathrm{~d}$ & $0.356 b c$ & $7.946 \mathrm{c}$ \\
\hline & B & $0.533 \mathrm{e}$ & $8.684 \mathrm{c}$ & $0.406 \mathrm{c}$ & $8.352 \mathrm{de}$ & $0.416 \mathrm{c}$ & $9.156 \mathrm{~cd}$ \\
\hline \multirow[t]{2}{*}{5} & V & $0.516 \mathrm{de}$ & $7.811 \mathrm{c}$ & $0.392 b c$ & $9.289 \mathrm{ef}$ & $0.397 b c$ & $9.873 \mathrm{de}$ \\
\hline & B & $0.538 \mathrm{e}$ & $8.788 \mathrm{c}$ & $0.414 \mathrm{c}$ & $9.649 \mathrm{f}$ & $0.441 \mathrm{c}$ & $10.514 \mathrm{e}$ \\
\hline
\end{tabular}

$\mathrm{PAI}=$ Plant age at the time of inoculation in weeks, $\mathrm{V}=$ virus inoculated plants, $\mathrm{B}=$ buffer inoculated plants. Values are means of four replicates. In each column, means followed the same letter are not significantly different according to Duncan's multiple range test at $\mathrm{P}=0.05$. Cultivars were harvested at 3 weeks after inoculation.

Table 3: Effect of buffer and Amaranthus mosaic virus inoculations on the dry weights (g) of leaf per plant and stem of the three Amaranthus cultivars.

\begin{tabular}{|c|c|c|c|c|c|c|c|}
\hline \multirow{2}{*}{\multicolumn{2}{|c|}{$\begin{array}{l}\text { PAI } \\
\text { (Weeks) }\end{array}$}} & \multicolumn{2}{|c|}{ NHAM/114 } & \multicolumn{2}{|c|}{ NH84/457-IL } & \multicolumn{2}{|c|}{ LOCAL GREEN } \\
\hline & & leaf & stem & leaf & stem & leaf & stem \\
\hline \multirow[t]{2}{*}{2} & $\mathrm{~V}$ & $0.054 \mathrm{a}$ & $0.117 \mathrm{a}$ & $0.024 \mathrm{a}$ & $0.443 \mathrm{a}$ & $0.027 \mathrm{a}$ & $0.261 \mathrm{a}$ \\
\hline & B & $0.073 b$ & $0.249 b$ & $0.038 \mathrm{~b}$ & $0.584 \mathrm{~b}$ & $0.053 b$ & $0.457 \mathrm{~b}$ \\
\hline \multirow[t]{2}{*}{3} & $\mathrm{~V}$ & $0.087 \mathrm{c}$ & $0.202 b$ & $0.039 \mathrm{~b}$ & $0.684 b c$ & $0.036 \mathrm{a}$ & $0.489 b$ \\
\hline & B & $0.096 \mathrm{c}$ & $0.312 \mathrm{c}$ & $0.055 \mathrm{c}$ & $0.834 \mathrm{~d}$ & $0.058 b \mathrm{c}$ & $0.694 \mathrm{c}$ \\
\hline \multirow[t]{2}{*}{4} & V & $0.108 \mathrm{~d}$ & $0.649 \mathrm{bc}$ & $0.047 b c$ & $0.792 \mathrm{~cd}$ & $0.059 b c$ & $0.765 \mathrm{~cd}$ \\
\hline & B & $0.116 \mathrm{~d}$ & $0.705 \mathrm{c}$ & $0.053 \mathrm{c}$ & $0.862 \mathrm{~d}$ & $0.067 \mathrm{c}$ & $0.843 \mathrm{~d}$ \\
\hline \multirow[t]{2}{*}{5} & V & $0.113 \mathrm{~d}$ & $0.716 c$ & $0.048 b c$ & $0.846 \mathrm{~d}$ & $0.065 b c$ & $0.813 \mathrm{~cd}$ \\
\hline & B & $0.117 \mathrm{~d}$ & $0.764 c$ & $0.052 \mathrm{c}$ & $0.893 \mathrm{~d}$ & $0.068 \mathrm{c}$ & $0.857 \mathrm{~d}$ \\
\hline
\end{tabular}

$\mathrm{PAI}=$ Plant age at the time of inoculation in weeks. V= virus inoculated plants, $\mathrm{B}=$ buffer inoculated plants. Values are means of four replicates. In each column, means followed the same letter are not significantly different according to Duncan's multiple range test at $\mathrm{P}=0.05$. Cultivars were harvested at 3 weeks after inoculation.

Table 4: Percentage reduction ${ }^{\mathrm{a}}$ in fresh and dry weights $(\mathrm{g})$ of leaf per plant of the three Amaranthus hybridus cultivars inoculated with Amaranthus mosaic virus.

\begin{tabular}{lcccccc}
\hline PAI & NHAM/114(\%) & \multicolumn{2}{c}{ NH84/457-IL (\%) } & \multicolumn{2}{c}{ LOCAL GREEN (\%) } \\
(Weeks) & Fresh & Dry & Fresh & Dry & Fresh & Dry \\
\hline 2 & $47 \mathrm{a}$ & $26 \mathrm{a}$ & $22 \mathrm{a}$ & $37 \mathrm{a}$ & $39 \mathrm{a}$ & $49 \mathrm{a}$ \\
3 & $20 \mathrm{~b}$ & $9 \mathrm{~b}$ & $19 \mathrm{~b}$ & $29 \mathrm{~b}$ & $29 \mathrm{~b}$ & $38 \mathrm{~b}$ \\
4 & $14 \mathrm{c}$ & $7 \mathrm{c}$ & $8 \mathrm{c}$ & $11 \mathrm{c}$ & $14 \mathrm{c}$ & $12 \mathrm{c}$ \\
5 & $4 \mathrm{~d}$ & $3 \mathrm{~d}$ & $5 \mathrm{~d}$ & $8 \mathrm{~d}$ & $10 \mathrm{~d}$ & $4 \mathrm{~d}$ \\
\hline
\end{tabular}

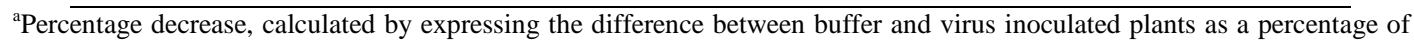
the value for the buffer. PAI- Plant age at the time of inoculation in weeks. Values are means of four replicates. In each column, means followed the same letter are not significantly different according to Duncan's multiple range test at $\mathrm{P}=0.05$. 
Table 5: Percentage reduction ${ }^{\mathrm{a}}$ in fresh and dry weights ( $\mathrm{g}$ ) of stems of the three Amaranthus hybridus cultivars inoculated with Amaranthus mosaic virus.

\begin{tabular}{lcccccc}
\hline PAI & \multicolumn{2}{c}{ NHAM/114 (\%) } & \multicolumn{2}{c}{ NH84/457-IL (\%) } & \multicolumn{2}{c}{ LOCAL GREEN (\%) } \\
(Weeks) & Fresh & Dry & Fresh & Dry & Fresh & Dry \\
\hline 2 & $49 \mathrm{a}$ & $53 \mathrm{a}$ & $27 \mathrm{a}$ & $24 \mathrm{a}$ & $56 \mathrm{a}$ & $43 \mathrm{a}$ \\
3 & $34 \mathrm{~b}$ & $35 \mathrm{~b}$ & $20 \mathrm{~b}$ & $18 \mathrm{~b}$ & $39 \mathrm{~b}$ & $29 \mathrm{~b}$ \\
4 & $14 \mathrm{c}$ & $8 \mathrm{c}$ & $6 \mathrm{c}$ & $8 \mathrm{c}$ & $13 \mathrm{c}$ & $9 \mathrm{c}$ \\
5 & $11 \mathrm{~d}$ & $6 \mathrm{~d}$ & $4 \mathrm{~d}$ & $5 \mathrm{~d}$ & $6 \mathrm{~d}$ & $5 \mathrm{~d}$ \\
\hline
\end{tabular}

${ }^{\text {a}}$ Percentage decrease, calculated by expressing the difference between buffer and virus inoculated plants as a percentage of the value for the buffer. PAI- Plant age at the time of inoculation in weeks. Values are means of four replicates. In each column, means followed the same letter are not significantly different according to Duncan's multiple range test at $\mathrm{P}=0.05$.

\section{DISCUSSION}

The present investigation has shown that the three Amaranthus cultivars are susceptible to Amaranthus mosaic virus (AMV). There have been reports of viruses infecting Amaranthus species in the tropics. This supports the findings of Brunt et al. (1994) who asserted AMV as one of the viruses of tropical plants. Moreso, the research of Taiwo and Owolabi (2004b) which compared Amaranthus leaf mottle and Amaranthus mosaic virus revealed that ALMV and AMV had fairly similar host ranges that included some species of Chenopodiaceae, Solanaceae and Amaranthaceae. The prevalence of AMV in A. hybridus cultivars was confirmed in this study from the results obtained on severity and plant biomass. This result is also in support of Taiwo and Owolabi (2004b) which stated that AMV is highly prevalent in commercially cultivated A. hybridus in Lagos, Nigeria and it causes considerable economic losses.

This study revealed that age of plant at the time of inoculation influenced the severity of infection in plants because early infection of A. hybridus resulted in more severe symptoms and also reduced both the fresh and dry weights of plants. These findings are in agreement with the report of Agrios et al. (1985) and Langham et al. (2005) which stated that the younger the plants at the time of viral infection the greater the severity of disease symptoms.

Furthermore, it was discovered that the younger the age of plants at inoculation the more the effect of AMV on all the parameters investigated in this study. This indicated a relationship between age at time of inoculation and virus effect. These results are in conformity with the observation made by Agrios et al. (1985) when they conducted a study on the effect of successive weekly inoculation of cucumber mosaic virus on the growth of pepper (Capsicum annum) plants. The results showed that the growth of the plants was drastically affected at the earlier stages compared to the later stages of inoculation.

In addition, significantly higher fresh and dry weight values were obtained for plants at later stage of growth than at an early stage. This agrees with the previous report of Owolabi and Taiwo (2001) who opined that the attainment of maturity by plants before inoculation could result in significantly higher fresh and dry weight values for plants. Similarly, the research of Kareem and Taiwo (2007) observed progressively reduced effects of viruses on cowpea cultivars infected by Cowpea mosaic virus (CABMV), Cowpea mottle virus $(\mathrm{CMeV})$ and Bean southern mosaic virus (SBMV) when inoculated at later stages of growth. When A. hybridus was 
mechanically inoculated with AMV, reductions in plant biomass were recorded in all the inoculated plants including those inoculated at later stages of growth. However, these plants that received late inoculation did not show any symptoms of infection. The non appearance of symptoms may be as a result of latent infection usually exhibited by matured plants. Latent infections in plants have been reported by many authors. Garcia-Ruiz and Murphy (2001) demonstrated the occurrence of mature plant resistance in Capsicum annuum (Early Calwonder) to Cucumber mosaic virus (CMV) under greenhouse conditions and they concluded that late inoculated plants were asymptomatic while early inoculated plant developed systemic symptoms. Odedara et al. (2009) affirmed the presence of latent infections by viruses in asymptomatic cowpea varieties by subjecting them to serological indexing using both antigen-coated plate enzyme-linked immunosorbent assay (ACP ELISA) and Protein A sandwich (PAS) ELISA.

Mechanical inoculation of the three $A$. hybridus cultivars with AMV revealed that all the cultivars were susceptible to the virus. This implies that mechanical transmission is one of the means by which the virus can be transmitted in this plant. Therefore, spread of AMV by this method should be avoided by restricting the movement of personnel and equipment through field-grown A. hybridus plants. Nonetheless, insect transmission of AMV on the field was the commonest method of transmission and this was reported by Taiwo and Owolabi (2004b) in which nonpersistent transmission of AMV by Aphis craccivora and Myzus persicae was demonstrated in the greenhouse. Planting of A. hybridus when insect vectors are out of season and use of integrated pest control management were suggested as means of controlling the insect vectors of AMV.

This study therefore concluded that
AMV had drastic effects on biomass and symptom induction at early age of infection while mild effects were recorded at later stage of inoculation of the three A. hybridus cultivars.

\section{ACKNOWLEDGEMENT}

We wish to appreciate the efforts of Late Professor M.A. Taiwo for the proper supervision of this work.

\section{REFERENCES}

Agrios GN, Walker ME, Ferro DN. 1985. Effects of cucumber mosaic virus inoculation at successive weekly intervals on growth and yield of pepper (Capsicum annum) plants. Plants Disease., 69: 52-59.

Brunt AA, Crabtree K, Dalwitz MJ, Gibbs A, Watson L. 1996. Viruses of Plants. Description and Lists from the Database. Wallingford, UK: CABI International, Cambridge: Cambridge University Press; 1484.

Czerwiński J, Bartnikowska E, Leontowicz H. 2004. Oat (Avena sativa L.) and amaranth (Amaranthus hypochondriacus) meals positively affect plasma lipid profile in rats fed cholesterol-containing diets. J. Nutr. Biochem., 15(10): 622-9.

Dhellot JR, Matouba E, Maloumbi MG, Nzikou JM, Safou-Ngoma DG, Linder M, Desobry S, Parmentier M. 2006. Extraction, chemical composition and nutritional characterization of vegetable oils: Case of Amaranthus hybridus (Var 1 and 2) of Congo Brazzaville. Afr. J. Biotechnol., 5(11): 1095-1101.

Fauquet CM, Fargette D. 1990. African Cassava Mosaic Virus: etiology, epidemiology and control. Plant Disease, 74: 404-411.

Garcia-Ruiz H, Murphy JF. 2001. Age-related Resistance in Bell Pepper to Cucumber 
mosaic virus. Ann Appl Biol., 139: 307317.

Gonor KV, Pogozheva AV, Derbeneva SA, Mal'tsev G, Trushina EN, Mustafina OK. 2006. The influence of a diet with including amaranth oil on antioxidant and immune status in patients with ischemic heart disease and hyperlipoproteidemia. Vopr Pitan., 75(6): 30-3.

Grogan RG. 1980. Control of Lettuce mosaic virus with virus free seeds. Plant Disease, 64: 446-449.

Harlan JR. 1992. Crop and Man (2 ${ }^{\text {nd }}$ edn). American Society of Agronomy: Madison, WI; 284p.

He HP, Corke H. 2003. Oil and squalene in Amaranthus Grain and leaf. J. Agric. Food Chem., 51(27): 7913-7920.

Kareem KT, Taiwo MA. 2007. Interaction of viruses in cowpea: effect on growth and yield parameters. Virology Journal, 4: 15.

Ladipo JL. 1988. Viruses of vegetable crops in Africa. In Virus Diseases of Plants in Africa, Williams AO, Mbiele AL, Nkouka N (eds). OAU/STRC Scientific Publication: Lagos, Nigeria, 157-167.

Langham MAC, Cihlar-Strunk CL, Hoberg AE. 2005. Evaluation of high pressure spray inoculation of bean pod mottle virus on yield and test weight of soybean. Phytopathology, 95: S164.

Lovisolo O, Lisa V. 1979. Studies on Amaranthus leaf mottle virus in the Mediterranean region. Phytopathologia Mediterranae, 18: 89-93.

Martin FM, Telek L. 1979. Vegetables for the hot humid tropics. Part 6: Amaranth and Celosia. US Dept. of Agric., New Orleans, LA.

Martirosyan DM, Miroshnichenko LA, Kulakova SN, Pogojeva AV, Zoloedov VI. 2007. Amaranth oil application for coronary heart disease and hypertension.
Lipids Health Dis., 6: 1.

Mepha HD, Eboh L, Banigbo DEB. 2007. Effects of processing treatments on the Nutritive Composition and consumer acceptance of some Nigerian edible leafy vegetables. Afr. J. Food Agric. Nutr. Dev., 7(1): 1-18.

Odedara OO, Hughes JD'A, Odu BO. 2009. Occurrence of latent virus infection in visually-rated cowpea (Vigna unguiculata L. Walp) seedlings. Archives of Phytopathology and Plant Protection, 42(9): 882-890.

Oke OL. 1983. Amaranthus. In Handbook of Tropical Foods, Chan Jr. HT (ed). Marcel Dekker, Inc.: New York; 1.

Oliveira JS, De Carvalho MF. 1975. Nutritional value of some edible leaves used in Mozambique. Econ. Bot., 29: 255.

Owolabi AT, Taiwo MA. 2001. Effect of Celosia mosaic virus on Celosia argentea L. Global Journal of Pure and Applied Science, 7(2): 209-212.

Phatak HC. 1975. Mosaic disease of Amaranthus: A new record of India. Current Science, 34(22): 645-646.

Rao CV, Newmark HL. 1998. Chemopreventive effect of Squalene on colon cancer. Carcinogenesis, 19: 287-290.

Rawate PD. 1983. Amaranth (pigweed): A crop to help solve the world protein shortage. In Environmentally Sound Agriculture: Selected papers from the $4^{\text {th }}$ International Conference of the International Federation of Organic Agriculture Movements, Lockeretz AW (ed). Praeger: NY; 287-298.

Reiz B, Leitzmann C. 1985. The contribution of home gardens in the improvement of human nutrition in the tropics and subtropics. Entwicklung and Landlicher Rawn., 19: 8-12.

Rogers H. 1969. Alfalfa mosaic virus. Advances in Virus Research, 15: 368- 
380.

Schmelzer K, Molnar K. 1975. Amaranthus retroflexus $\mathrm{L}$. an important reservoir of the cucumber mosaic virus in Hungary. Acta Phytopathologia Academia Scientarum Hungaricae, 10(4): 114-120.

Singh S, Verma A, Chenulu VV, Verma VS. 1972. Pigweed mosaic virus. Phytopathol., 75: 82-85.

Smith TJ. 2000. Squalene: Potential Chemo preventive agent. Expert Opin. Invest. Drugs, 9: 1841-1848.

Taiwo MA, Thottapppily G, Shoyinka SA. 1988. Studies on a virus disease of
Amaranthus hybridus L. in Nigeria. Int. J. Trop. Dis., 6: 195-200.

Taiwo MA, Owolabi AT. 2004a. Occurrence and prevalence of viruses of leafy vegetables in Lagos, Nigeria. Global J. Pure Appl. Sci., 10(1): 61-67.

Taiwo MA, Owolabi AT. 2004b. Comparative study of Amaranthus leaf mottle virus genus Potyvirus and Amaranthus mosaic virus. Journal Sci. Res. Dev., 9: 63-74.

Weaver SE, McWilliams EL. 1980. The biology of Canadian weeds. Amaranthus retroflexus L., A. powellis. Wats and $A$. hybridus L. Plant Sci., 60: 1215-1234. 